\title{
A framework for caring in the human resource management process of nurses
}

\author{
A Minnaar, PhD, School of Nursing, Decentralised Programmes, University of Natal
}

\begin{abstract}
The aim of this paper is to describe the provision of a human value system in nursing management that would lead to an environment conducive to quality of care to nurses. Caring is a complex phenomenon with caring concepts which emphasized the human element in human resource management in the health services. Watson (1985) focused on the philosophical and spiritual basis of caring. The ten carative factors as described by Watson (1985) were used as a framework for the application of caring to the human resource management process in nursing. This framework enables a basis for the development of a caring environment for the nurse manager, in which the nurse could experience caring. It served as a point of departure for a research study undertaken during 2000 on caring to the caregivers in health services.
\end{abstract}

\section{Opsomming}

Hierdie artikel poog om die voorsiening van 'n menslike waardestelsel in verpleegbestuur daar te stel wat aan verpleegkundiges ' $n$ sorg (caring )omgewing wat tot die kwaliteit van sorg aan verpleegkundiges bydra. Sorg (caring) is ' $n$ komplekse verskynsel met sorgkonsepte wat die menslike element in menslike hulpbronbestuur binne gesondheidsdienste beklemtoon. Watson (1985) fokus op die filosofie en spirituele basis van sorg. Die tien sorg (caring) faktore soos deur Watson (1985) beskryf, is as ' $n$ raamwerk vir die toepassing van sorg in die menslikehulpbronbestuursproses van verpleegkundiges benut. Hierdie raamwerk verskaf ' $n$ basis vir die ontwikkeling van " $n$ omgewing waarin die verpleegkundige sorg (caring) kan ervaar. Die raamwerk het as vertrekpunt vir ' $n$ navorsingstudie gedien waar sorg aan die sorgverleners bestudeer is.

\section{Introduction}

Concepts of caring in health services are well defined and described in the literature. Watson in Molzahn (1996:247) views caring as 'the moral ideal of nursing whereby the end is protection, enhancement and preservation of human dignity'. The nature of caring with emphasis on the nurse/patient interaction has been researched and described by various authors. For the purpose of this paper the emphasis will be on caring in the human resource management process of nurses, according to the caring theory of Watson (1985).

Limited emphasis is placed on the implementation of caring concepts in human resource management in nursing according to Shriber and Larson (1991:57). Most literature concentrates on patient's expectations of caring, with little description of the how nurses view caring with the result that too little emphasis is placed on the meaning of caring in human resource management of nurses (Nyberg 1993:11, Boykin and Schoenhofer 1990:149). This paper explains a framework for the application of Watson's Caring Theory in the human resource management process of nurses.

\section{Significance of caring in human resource management in nursing}

In the current health care services in South Africa more emphasis is being placed on quality care than in the past. The key to quality in nursing services is, according to Molzahn (1997: 247) the creation of a caring culture in health care organizations. Within a caring culture, the human dignity of both patients and staff will be preserved. Bringing the ethic of care and responsibility into dialogue with the general public will ensure human rights, a practice of commitment and quality nursing care (Molzahn 1997:249).

The research findings by Minnaar (1994:85) on the importance of the concept of caring to nursing personnel, indicated that nurse managers are aware of the importance of caring in nursing management but nurses did not voice experiences of being cared for in the management environment of the health services. Nurses indicated that their experience of caring in the nursing management environment were only moderate to poor. Caring is a complex phenomenon and the importance of caring concepts in human resource management in the health services need to be emphasized.

\section{The application of the caring theory of watson (1985) in the hu- man resource management proc- ess of nurses $b$ a framework}

Watson (1985:7) describes caring in nursing practice as a therapeutic interpersonal process with the assumption that caring can be effectively demonstrated and practiced only interpersonally. Watson (1985) emphasizes the fact that caring 
is a deeply human activity as described by Kyle (1995: 507). Caring has existed in every society. A caring attitude is not transmitted from generation to generation by genes, but by the culture of the caring professions. Nurse managers play a major role in setting the culture of a health service. There is often a discrepancy between theory and practice and the reason may be the difference between scientific and humanistic values (Watson 1985: 12). Watson (1985: 8) identifies basic assumptions for a science of caring as follows:

\section{The seven basic assumptions for a science of caring of watson (1985:8)}

Watson (1985:10) identified ten carative factors in nursing practice: These ten factors form the framework for understanding and studying the science of caring. Watson (1985:12) emphasized that no one of the factors could be implemented on its own, and stressed the importance of the first three carative factors in providing a philosophical foundation for caring in nursing. The provision of a human value system in nursing management would give nurses an environment conducive to quality nursing care. Nurses should nurture hope in their patients and the nurturing of hope in the management environment could contribute to the willingness of nurses to instill hope in their patients and contribute to the recovery process.

\section{The ten carative factors for a science of caring of watson (1985:9)}

Watson (1985:10) stated that the recognition and development of feelings helped in the self-actualization and growth of a person. She singled out the main responsibility of human resource management as being to help nurses towards growth and self-actualization and to enable them to encourage growth in others. According to Watson (1985:10) the first three factors are interdependent and function together in a process that promotes positive changes in the individual.

These carative factors are valuable reminders of the steps we must take if we are to give others what they really need from us as caregivers (Stickland 1996:10).

\section{Factor 1 The formation of a humanistic-altruistic system of values.}

The formation of a humanistic-altruistic system of values in nursing management is the basis for caring and should guide all management decisions. Caring leaders establish with each nurse a dynamic process of exchanges, interaction and open communication. Caring has been found to be a complex set of affective, cognitive and interactional elements which are put into purposeful action between nurse managers and nurses (Bergen 1999:39). Nurse managers should work at remembering nurses' names and discovering each one's unique pro- fessional and personal needs. The following are universal human needs in any interactive situation:

Friendliness In the human resource environment friendliness is a basic and sometimes neglected caring concept. Greeting the nurses in a friendly way or addressing them by their names shows the nurses that nurse managers are interested in them as individuals (Brand 1994:69).

Kindness To say that caring is being nice or kind is to miss the cognitive aspects of caring (Valentine 1989: 30-31). Kindness is a part of the other caring elements in a caring relationship. Nurse managers could show kindness by accepting the nurse as an individual with specific needs. Nurse managers should assess the needs of nurses and try to accommodate these needs (Wadas 1993:40).

Concern People are the greatest asset of any organisation. Caring human resource management affirms the uniqueness, importance and potential of every individual nurse. Caring for and about the nurses combines justice, equity and respect with genuine concern. When nurses feel valued and appreciated by the nurse manager, they are motivated to give their best when they care for patients (Wolf 1986:86).

Love According to Brandt (1994: 69) good management is largely a matter of love. Managers must have the courage to care for the good things the health service can do in the community, as well as caring for the caregivers. Dedication to the common goal of nursing is what patient care is all about. Management of nurses is like being in love and the courage to care is the challenge for health services of today. Nurses should be viewed as partners rather than subordinates. Nurse managers should see the needs of the employees (nurses) as no different from their own needs. Caring is seen by Fromm (1957) as a basic element of love, but it must be infused with knowledge (Morrison \& Cowley 1999:30)

Caring should be grounded in humanistic values such as kindness, empathy, concern and love for others and altruistic values that bring meaning to one $=\mathrm{s}$ life through relationships with other people (Watson 1985:12).

\section{Factor 2 The instilling of faith and hope}

The emphasis on faith and hope in the human resource management process should be a natural development from the humanistic-altruistic system of values. The instilling of faith and hope should ensure a professional and positive environment in nursing management and is never a completed process. The nurse manager should instil faith and hope in each one of her/his nursing personnel. The instilling of faith and hope would contribute to the most important caring task in human resource management, which is to encourage nurses to believe in their own potential to care for patients and their families (Wadas 1993:4). The instilling of faith and hope in patients is basic to the healing process and helps to determine the outcome of disease. A person's mind and soul should be inspired before the illness can be treated (Watson 1985: 13-16).

\section{Factor 3 The cultivation of sensitivity to oneself and to others}

Sensitivity to oneself and to others is grounded on the formation of a humanistic-altruistic system of values with the aim 
of satisfaction, comfort, and a high level of health (in nursing management this means low stress levels and no burnout of nurses). Burnout results when the individual is not allowed to develop, and when the individual works in an organization that is only bottom line driven. Without the cultivation of sensitivity to oneself and to others, nursing care would fail, because nurses need to be sensitive towards their own needs and to the needs of others to develop the ability to learn about another person's view of the world (Watson 1985:17).

The nurse manager should try to help nurses to develop a sensitivity towards their own feelings. People who are not sensitive towards their own feelings, might find it difficult to be sensitive and responsive to feelings of others. If nurses fail to be human in sensitive situations, then they fail in their nursing task, to nurse and care for the patient (Watson 1985:19).

In a management environment sensitivity provides a climate for understanding and acceptance of nurses as individuals with individual needs. Moving towards higher levels of maturity and self-actualization is only possible when nurses are accepted and understood by nurse managers. Watson (1985:19) believes that the more self-actualized a person is, the higher is his/her quality of living. Self actualization is the need to maximize one's potential. Nurse managers have a major role to play in helping nurses towards self actualisation. Management performance is an opportunity for managers where. nurses could be encouraged towards further development of potential. Individual needs could be identified and career goals could be set, and planning towards career goals could be facilitated.

Competence is a major desire of human beings. In human resource management of nurses, insistence on competence is of special importance, since patients expect high levels of competence from nurses. Nurse managers could help to improve the competence of nurses by providing means for professional growth and development.

\section{Factor 4 The development of a helping-trusting relationship between the care-receiver and the caregiver to ensure a relationship of quality.}

A helping-trusting relationship evolves from a certain quality of congruence, empathy, warmth. communication and listening. Patients and others that feel another person really cares about them are more likely to establish a trusting relationship with that person. The first three factors namely, the formation of a humanistic-altruistic system of values, the instilling of faith and hope, and the cultivation of sensitivity to oneself and to others, determine the quality of the relationship. The nurse who experiences caring in the human resource management situation will be more willing to discuss sensitive information concerning herself and her problems and needs with the nurse manager, with the possibility that nurses could become more sensitive to the needs of patients under her/his care. Watson (1985:25) states that patients showed signs of receiving high quality care when they experienced good interpersonal relations with nurses. A basic element of quality care is the development of a helping-trusting relationship (Molzahn 1997:247). Knowledge of the other person is of utmost importance. For the helping-trusting relationship certain attitudinal processes, for example, sensitivity to self, openness and altruism, are prerequisites. Other processes that are interrelated to the helping-trusting relationship are as follows:

Congruence is a critical element in the helping-trusting relationship and is tied to sensitivity to self and others that includes an openness towards feelings. Guidelines for congruence in nursing management are honesty at all times, and genuineness and openness on the side of the nurse manager. Honesty must be shown in identifying problems in the health services and a readiness to communicate with nurses (Watson 1985:26).

Empathy is a basic element essential for the development of a helping-trusting relationship. Empathy refers to the ability to experience the other person=s personal world and feelings. It includes the ability to communicate understanding to the other person. According to Watson (1985:28) the working conditions of nurses could change positively for nurses with the understanding and acceptance of nurses in the human resource management environment (Yegdich 1999:84). Nurse managers should show appreciation and understanding of the work that nurses do.

Warmth refers to the degree to which the nurse manager communicates caring to others. Warmth could be communicated to others in a variety of ways, for example, gestures, posture, tone of voice, touch and facial expressions (Watson 1985:32) These aspects are important aids that could be used by the nurse manager in handling difficult human resource management aspects such as dealing with discipline and handling of grievances. Chappel (1993:218) as cited in Kerfoot (1997:51) notes that people from happy, loving families will do anything for each other as will people who work for happy loving companies.

Communication with effective feedback to nurses will ensure the development of effective helping-trusting relationships. Open communication helps to facilitate a trusting relationship in nursing between nurse manager and nurses (Watson 1985:23). The nurse manager should maintain open communication channels with staff (Dyson 1996:263). The majority of grievances in nursing are the direct result of management failing to listen to their staff (Potgieter \& Muller, 1998:14-23). Effective listening skills should be developed by nurse managers to ensure a helping-trusting relationship in the human resource management environment of nurses (Strickland 1996:6-9).

Nurse managers should concentrate on maintaining relationships and avoiding thoughtless things that might damage the relationship between management and nurses. Nurse managers should concentrate on setting the right example to staff, the caring role model, and being consistent in temperament so that nurses know how to read the nurse manager. The nurse manager must always try to be fair, impartial, and consistent regarding staffing matters, for example, applying the rules, executing discipline procedures and rewarding nurses. A sincere personal interest in nursing staff as individuals, and counselling staff on matters that affect their jobs are important 
eses;

Evaluation Deciding whether hypotheses are correct, making criterion-based evaluations and judgments (Watson

Factor 5 The promotion and acceptance of the expression of positive and negative feelings.

This factor forms an inherent part of the helping-trusting relationship and encourages a move to a deeper and more honest level of the relationship between nurse management and nurses. This factor seems to be so basic that it could easily be taken for granted. In reality this factor is often not recognized or used in the most effective way. It includes aspects such as communication and interaction between people. This factor is important for the nurse manager in the human resource management position because communication and interaction form part of the functions of nurse managers (Watson 1985:41).

\section{Factor 6 The systematic use of the scientific problem-solving method for decision-making.}

A creative problem-solving approach is the basis of a science of caring in patient care. The emphasis is on the art and science of caring in nursing. The use of the scientific problemsolving decision-making method is as important as the human caring approach in nursing. According to Watson (1985), a student in nursing needs additional knowledge and understanding for the application of the scientific problem-solving decision-making method in nursing. Firstly nurses must have the conceptual and theoretical understanding of a phenomenon or a problem, and theoretical background to solve the problem (Nyberg 1989:12). Nurse managers could set the example for scientific problem-solving in nursing by using this method when solving patient care problems, together with the nurses.

The scientific problem-solving decision-making process tries to solve problems or answer questions and was introduced as a method of nursing that considers an individual=s physical, social, psychological reactions to disease, the individual as a member of society with his own stresses which may affect her/his reaction to disease (Morrison \& Cowley 1999:26). Nursing, as a science of caring, becomes a more complete science and profession as it incorporates systematic use of the scientific problem solving method (Watson 1985: 59).

The scientific process of nursing includes the following processes:

Assessment Observing, distinguishing relevant from irrelevant data, distinguishing important from unimportant data, validating data, organizing data and categorizing data;

Analysis/diagnosis Finding patterns and relationships, making inferences, stating the problem and suspending judgment; Planning Generalizing, transferring knowledge from one situation to another, developing evaluative criteria and hypothesizing;

Implementation Applying knowledge and testing hypoth1985:65).

\section{Factor 7 The promotion of interpersonal teaching and learning.}

Learning is more than receiving information, as it also depends on the nurse's ability to accurately scan, assess, formulate, appraise, plan, implement, evaluate and to make a decision. Nurse managers have a major task to ensure that all nurses are sufficiently skilled and knowledgeable to cope with modern demands. The factor of interpersonal teaching and learning is part of nearly all nursing interventions with patients/nurses/others (Grigsby \& Megel 1995:441). Watson (1985:74) identifies seven clinical care phases for problemsolving in the interpersonal teaching-learning process:

Scanning Identify the major problems and goals that are important to the specific person. Discover potential as well as actual problems within the other person=s framework according to his/her own perceptions. The nurse manager could use scanning to help with identification of staff problems in time, and to be able to plan interventions (Watson 1985:76).

Formulating This includes exploring the issue of concern and examining the significance of the problem together with the nurse.

Appraising A joint decision about the problem is taken, with willingness to solve it on both sides, including nurse managers and nurses (Watson 1985:77).

Problem solving This phase involves the willingness to solve the problem, to take action and to learn from the experience. The helping-trusting relationship and interpersonal processes become critical elements at this stage. The nurse manager and nurses should display honesty, empathy, warmth and a commitment towards learning and problem-solving in the nursing management environment (Watson 1985:78).

Planning Includes joint decision-making by nurse managers and nurses and the identification of ways in which to solve the problem. Active participation on both sides to generate alternatives is of critical importance.

Implementing This stage includes traditional learning such as cognitive information. The nurse manager with her/ his higher level of experiences should take the lead and teach the nurses how to implement decisions;

Evaluation At this stage whether or not the learning did in fact takes place is investigated (Watson 1985: 78).

\section{Factor 8 The provision of a supportive, protective, and (or) corrective mental, physical, socio- cultural, and spiritual environment.}

The goal of this carative factor is to strengthen the self-concept and self-worth of nurses through a holistic approach to the health environment. This carative factor emphasizes the lower needs of Maslow. The nurse manager could support the nurses towards motivation and success by acknowledgment of their achievements. The implementation of management by objectives and the provision of guidelines to attain the ob- 
jectives could motivate the nurses. The following are important for the provision of a supportive, protective, and (or) corrective mental, physical, socio-cultural, and spiritual environment as described by Watson (1985:80)

Comfort The nurse manager could control stress and provide comfortable working conditions by ensuring that nurses are well equipped for the task ahead and that enough competent nurses are employed with enough equipment and resources to care for the patients (Watson 1985:88).

Privacy This is a major factor in caring in the sense that the privacy of an individual must always be respected. Depersonalisation that sometimes occurs during hospitalisation contributes to the factor of privacy in nursing. Privacy is often linked to health and well being. Maslow's early findings showed that healthy people have a strong liking for privacy or even a need for it. Privacy maintains the nurse's human dignity and integrity. A violation of privacy could mean a violation of a nurse's dignity. All personal information should be treated as confidential by the nurse manager and the nurses (Watson 1985: 93).

Safety This is a basic human need, a basic function of the nurse manager and the nurse is to ensure the safety of all individuals working or users of the service, and a critical consideration in the health of patients. The nurse manager and the nurses must be constantly on the alert to safety factors in health services for both the patients and nurses (Watson 1985: 96-98).

Environment This factor includes more than safety and comfort. It is the provision of support, protection and correction of the environment. Cleanliness is closely linked with quality care. Watson (1985:98-100). Nurse managers should visit the units in the hospitals and acquaint themselves with the conditions under which nurses have to work. Nurse managers should ensure that the environment in the hospital is conducive to health and safety of all concerned.

\section{Factor 9 Assistance with the gratification of human needs.}

It is important to the nurse managers and the nurse's role to help others in their daily activities as well as facilitating growth and development of patients towards health. Watson (1985:104) classified Maslow's needs as follows, for the purpose of nursing:

Lower order needs (survival needs) that include food and water, elimination and ventilation and the functional needs that include activity and rest (Watson 1985:105).

Higher order needs (integrated needs) that include aspects such as success and affiliation and the growth-seeking needs that include needs of self- actualisation (Watson 1985:106).

This order of needs could be useful to the nurse manager to assess the individual needs of nurses. It is important for nurse managers to assess the needs of nurses towards self-actualisation as well to provide opportunities for fulfilment of these needs. The most important aspect for nurse managers is to mend broken spirits and to develop a supportive work atmosphere that encourages worker involvement and fosters employee growth (Watson 1985: 198).
The goal of nurse managers is to create an environment in which nurses may live up to their potential or at the highest level of need attainment. Nurse managers should care about what nurses think, feel and believe. Nurse managers, who still believe in old outdated approaches, like using threats and intimidation to get results, need to rethink their position. Caring is the chief building block upon which new business and professional relationships should be built (Bickham 1996:47).

\section{Factor 10 The allowance for existential-phenomenological forces.}

This factor emphasizes understanding of people from their frame of reference in order to help the person to find his or her own meaning and solution to problems. The understanding of people from their frame of reference is an ideal, and different situations will allow different levels of caring in the health services (Watson 1985:209). Nurse managers should try to understand the nurses from their (the nurses) frame of reference for better identification of the individual needs and problems of nurses.

\section{Conclusion}

The importance and the need for caring in patient care environments demand the application of caring concepts in the human resource management process of nurses. The description of the ten caring factors from Watson's theory in relation to the human resource management process could be used by nurse managers as a framework in which caring in nursing management could be implemented. This framework enables development of a caring environment in nursing management in which nurses could experience caring.

Watson (1985) cited in Boykin and Schoenhofer (1990:149155) provides insight as to what it entails when a nurse is caring for a patient. Watson mentions that caring is expressed through commitment, compassion, confidence, conscience and competence. These caring concepts are of considerable importance in the human resource management process in nursing. Health services should provide a human environment for nurses to practise nursing with the enactment of values such as commitment, support and the development of human resources, sensitivity to the needs of nurses, helping and trusting relationships with nurses and the provision of a safe and protective environment. Kerfoot (1997:50) emphasised that a leader's greatest gift to followers is a community of caring.

\section{References}

BARKER.PJ; REYNOLDS,W \& WARD, T 1995: The proper focus of nursing: A critique of the caring ideology. International Journal of Nursing studies. (4), 1995:386-797.

BERGEN, A 1999: An Analysis of caring: (In I.J. Norman and S. Cowley Editor: The Changing Nature of nursing in a managerial Age. London: Blackwell Science Ltd, pp36-51) 
BENNER, P \& WRUBEL, J 1989: The primacy of caring and coping in health and illness. Menlo Park:Addison-Wesley.

BICKHAM, W 1996: Liberating the human spirit in the workplace. Professional Publishing: Chicago.

BOYKIN, A \& SCHOENHOFFER, S 1990: Caring in nursing: Analysis of extant theory. Nursing Science Quarterly. (4). 1990: 149-155.

BRANDT, MA 1994: Caring leadership: Secret and path to success. Nursing Management. (8). 1994:68-72.

DYSON, J 1995: Nurses' conceptualisations of caring attitudes and behaviours. Journal of Advanced Nursing. (23), 1996: 1263-1269.

GRIGSBY, KA \& MEGEL, ME 1995: Caring experiences of nurse educators. Journal of Nursing Education. (9),1995: 411-418.

KERFOOT, K 1997: Leadership - The courage to care. Nursing Economics. (1), 1997:50-51.

KYLE,VK 1995: The concept of caring: a review of the literature. Journal of Advanced Nursing.(21). 1995:506-514.

MINNAAR, A 1994: Die aard van sorg aan verpleegpersoneel - 'n Verpleegbestuursperspektief.B Unpublished MA (Cur) dissertation. Pretoria: Unisa.

MOLZAHN, AE 1997: Creating caring organization cultures in dialysis units. ANNA Journal. (2), 1997: 247-253.

MORRSON, K \& COWLEY, S 1999: Idealised Caring: The heart of Nursing: In I.J. Norman and S. Cowley Eds: The Changing Nature of nursing in a managerial Age. London: Blackwell Science Ltd, pp 36-51)

NYBERG, J 1989: The element of caring in nursing administration. Nursing Administration Quarterly. (3), 1989:916.

NYBERG, J 1993: Teaching caring to the nurse administrator. Journal of Nursing Administration. (1), 1993:11-17.

POTGIETER, S \& MULLER, M 1998: Griewe in SuidAfrikaanse hospitale: 'n geskiedkundige-verpleegkundige perspektief. Curationis. (4), 1998:14-23.

RAY, M 1995: The edge of Chaos Caring and the Bottom Line. Nursing Management. (26), 1995: 48-50.

SHIBER, S \& LARSON, E 1991: Evaluating the quality of caring: Structure, process, and outcome. Holistic Nursing Practice. (3), 1991: 57-66.

STICKLAND, D 1996: Applying Watsons Theory for caring among elders. Journal of Gerontological Nursing. (22), 1996: 6-11.
VALENTINE, KL 1989: The Value of Caring Nurses. Ph.D. Dissertation, Graduate School of Cornell University.

VALENTINE, KL 1989: Caring is more than kindness: Modelling its complexities. Journal of Nursing Administration. (11),1989: 28-35.

WADAS, TM 1993: Case management and Caring Behavior. Nursing Management. (24), 1993: 40-46.

WATSON, J 1985: Nursing, Human Science and Human Care: A Theory of Nursing. Norwalk:CT Appleton.

WEBB, C 1996: Caring, curing, coping: towards an integrated model. Journal of Advanced Nursing. (23), 1996:960968.

WOLF, Z R 1996: The caring concept and nurse identified caring behaviors. Topics in Clinical Nursing. (8), 1996: 8493.

YEGDICH, T 1999: On phenomenology of empathy in nursing: empathy or sympathy? Journal of Advanced Nursing. (1) 1999: 83-93. 